\title{
Correction to: The Public Power of Judgement: Reasonableness Versus Rationality_-Setting the Ball Rolling
}

\author{
Karolina M. Cern ${ }^{1}\left[\right.$. José Manuel Aroso Linhares ${ }^{2}[$. \\ Bartosz Wojciechowski ${ }^{3}$ (D)
}

Published online: 8 January 2020

(c) The Author(s) 2020

\section{Correction to: Int J Semiot Law https://doi.org/10.1007/s11196-019-09659-8}

In the original publication of the article, the paragraph beginning "We begin with two steps or lawyers..." should read as "We begin with two steps or layers privileging jurisdictio as potestas, the first one devoted to a meta-dogmatic global approach, the second one facing specific institutionalizing issues."

Publisher's Note Springer Nature remains neutral with regard to jurisdictional claims in published maps and institutional affiliations.

The original article can be found online at https://doi.org/10.1007/s11196-019-09659-8.

Karolina M. Cern

cern@amu.edu.pl

José Manuel Aroso Linhares

linhares@fd.uc.pt

Bartosz Wojciechowski

bwojciechowski@wpia.uni.lodz.pl

1 Faculty of Philosophy, Adam Mickiewicz University, Szamarzewskiego Street 89C, 60-568 Poznan, Poland

2 Full Professor of Legal Theory and Philosophy of Law (Faculty of Law), University of Coimbra Institute for Legal Research (UCILeR), The University of Coimbra, Coimbra, Portugal

3 Faculty of Law and Administration, University of Lodz, Ul. Kopcinskiego 8/12, 90-232 Lodz, Poland 